Andrew T. Breshears, Charles L. Barnes, Durgesh V. Wagle, Gary A. Baker, Michael K. Takase, and Justin R. Walensky*

\title{
Structure and spectroscopy of uranyl and thorium complexes with substituted phosphine oxide ligands
}

\begin{abstract}
Phosphine oxide ligands are important in the chemistry of the nuclear fuel cycle. We have synthesized and characterized a series of phosphine oxide ligands with polycyclic aromatic hydrocarbon (PAH) groups to enhance the spectroscopic features of uranyl, $\mathrm{UO}_{2}^{2+}$, and to make detection more efficient. Complexation of $\mathrm{OPPh}_{2} \mathrm{R}, \mathrm{R}=\mathrm{C}_{10} \mathrm{H}_{7}$ (naphthyl); $\mathrm{C}_{14} \mathrm{H}_{9}$ (phenanthrenyl); $\mathrm{C}_{14} \mathrm{H}_{9}$ (anthracenyl); and $\mathrm{C}_{16} \mathrm{H}_{9}$ (pyrenyl), to $\mathrm{UO}_{2}\left(\mathrm{NO}_{3}\right)_{2}$ afforded the eight-coordinate complexes, $\mathrm{UO}_{2}\left(\mathrm{NO}_{3}\right)_{2}\left(\mathrm{OPPh}_{2} \mathrm{R}\right)_{2}$. An eleven-coordinate complex, $\mathrm{Th}\left(\mathrm{NO}_{3}\right)_{4}\left[\mathrm{OPPh}_{2}\left(\mathrm{C}_{14} \mathrm{H}_{9}\right)\right]_{3}, \mathrm{C}_{14} \mathrm{H}_{9}=$ phenanthrenyl, was structurally characterized, and was found to be the first thorium compound isolated with three phosphine oxide ligands bound. The phosphine oxide ligands were not fluorescent but the anthracenyl-substituted ligand showed broad, red-shifted emission at approximately $50 \mathrm{~nm}$ relative to typical anthracene, making this ligand set a possibility for use in detection. The synthesis and spectroscopy of the uranyl and thorium complexes are presented.
\end{abstract}

Keywords: Uranyl, Thorium, Phosphine Oxide, X-ray crystallography, Fluorescence.

DOI 10.1515/ract-2014-2295

Received May 27, 2014; accepted September 11, 2014

\section{Introduction}

With the increasing population of the world comes a rise in energy consumption which requires diverse solutions. All indications are that nuclear power will remain an im-

\footnotetext{
*Corresponding author: Justin R. Walensky, Department of Chemistry, University of Missouri, Columbia, MO 65211, USA, e-mail: walenskyj@missouri.edu

Andrew T. Breshears, Charles L. Barnes, Durgesh V. Wagle, Gary A. Baker: Department of Chemistry, University of Missouri, Columbia, MO 65211, USA

Michael K. Takase: Beckman Institute, California Institute of Technology, Pasadena, CA 91125, USA
}

portant player for many years. However, the advancement of nuclear energy has the consequence of developing nuclear weapon capability, and to combat these new methods for sensing actinides in complex matrices need to be developed. Uranyl nitrate, $\mathrm{UO}_{2}\left(\mathrm{NO}_{3}\right)_{2}$, is a major species throughout the reprocessing step of the nuclear fuel cycle, and therefore we are interested in investigating how to exploit the properties of $\mathrm{UO}_{2}^{2+}$ to enhance its detection. One prominent feature of $\mathrm{UO}_{2}^{2+}$ is its phosphorescence; however, in general, this phosphorescence is quite weak, and our approach is to amplify this property.

Phosphine oxide ligands are ubiquitous in actinide chemistry. For example, tributyl phosphate (TBP), $\mathrm{OP}\left(\mathrm{O}^{\mathrm{n}} \mathrm{Bu}\right)_{3}$, is used in the PUREX process in solvent extraction of uranyl into the organic phase. Due to this, many phosphine oxide ligands have been found to coordinate to the actinyl moiety. For example, $\mathrm{AnO}_{2}\left(\mathrm{NO}_{3}\right)_{2}\left(\mathrm{OPPh}_{3}\right)_{2}$, $\mathrm{An}=\mathrm{U}, \mathrm{Np}[1], \mathrm{Pu}[2], \mathrm{AnO}_{2} \mathrm{Cl}_{2}\left(\mathrm{OPPh}_{3}\right)_{2}, \mathrm{An}=\mathrm{U}[3]$, $\mathrm{Np}$ [1] and $\mathrm{UO}_{2}\left(\mathrm{O}_{2} \mathrm{CCH}_{3}\right)_{2}\left(\mathrm{OPPh}_{3}\right)_{2}$ [4] have been shown to make actinyl complexes. However, to our knowledge, uranyl complexes with phosphine ligands bearing polycyclic aromatic hydrocarbons (PAHs) have not been reported. Our rationale for using these ligands is to enhance the spectroscopic properties of uranyl and use a phosphine oxide ligand that would be more robust than TBP to radiolysis [5]. Herein, we report the synthesis, characterization, and spectroscopy of uranyl nitrate complexes with phosphine oxide ligands bearing a $\mathrm{PAH}$, $\mathrm{UO}_{2}\left(\mathrm{NO}_{3}\right)_{2}\left(\mathrm{OPPh}_{2} \mathrm{Ar}\right)_{2}, \mathrm{Ar}=$ naphthyl, anthracenyl, phenanthrenyl, and pyrenyl.

\section{Experimental}

All reactions were conducted in air unless otherwise specified. $\mathrm{UO}_{2}\left(\mathrm{NO}_{3}\right)_{2}\left(\mathrm{H}_{2} \mathrm{O}\right)_{6}$ was used as is from legacy stock, $\mathrm{Th}\left(\mathrm{NO}_{3}\right)_{4}\left(\mathrm{H}_{2} \mathrm{O}\right)_{4}$ (Strem) was used as received. All other chemicals were purchased (Aldrich) at $95 \%$ or higher purity and used as received. All ${ }^{1} \mathrm{H},{ }^{13} \mathrm{C}$, and ${ }^{31} \mathrm{P}$ NMR data were obtained on a $250 \mathrm{MHz}$ ARX, $300 \mathrm{MHz}$ DRX or $500 \mathrm{MHz}$ DRX Bruker spectrometer. ${ }^{1} \mathrm{H}$ NMR shifts given 
were referenced internally to the residual protio impurities at $\delta 5.32 \mathrm{ppm}\left(\mathrm{CDHCl}_{2}\right) .{ }^{13} \mathrm{C}$ NMR shifts were referenced internally to the residual peaks at $\delta 53.52 \mathrm{ppm}\left(\mathrm{CD}_{2} \mathrm{Cl}_{2}\right)$. ${ }^{31} \mathrm{P}$ NMR spectra were externally referenced to $0.00 \mathrm{ppm}$ with $85 \% \mathrm{H}_{3} \mathrm{PO}_{4}$ in $\mathrm{D}_{2} \mathrm{O}$. Infrared spectra were recorded from $\mathrm{KBr}$ pellets on a Perkin-Elmer Spectrum One FT-IR spectrometer. Absorbance spectra were obtained using a Varian Cary 50 Bio UV-Vis spectrophotometer and luminescence spectra were acquired on a Varian Cary Eclipse fluorimeter. Elemental analyses were performed by Atlantic Microlab, Inc. (Norcross, GA).

\subsection{Synthesis of phosphines and phosphine oxides, 1-4}

Phosphines $\mathrm{P}\left(\mathrm{C}_{6} \mathrm{H}_{5}\right)_{2}\left(\mathrm{C}_{10} \mathrm{H}_{7}\right)\left(\mathrm{C}_{10} \mathrm{H}_{7}=\right.$ naphthyl) [6], $\mathrm{P}\left(\mathrm{C}_{6} \mathrm{H}_{5}\right)_{2}\left(\mathrm{C}_{14} \mathrm{H}_{9}\right),\left(\mathrm{C}_{14} \mathrm{H}_{9}\right.$ = phenanthrenyl), $\mathrm{P}\left(\mathrm{C}_{6} \mathrm{H}_{5}\right)_{2}$ $\left(\mathrm{C}_{14} \mathrm{H}_{9}\right), \quad\left(\mathrm{C}_{14} \mathrm{H}_{9}=\right.$ anthracenyl $), \quad \mathrm{P}\left(\mathrm{C}_{6} \mathrm{H}_{5}\right)_{2}\left(\mathrm{C}_{16} \mathrm{H}_{9}\right)$, $\left(\mathrm{C}_{16} \mathrm{H}_{9}=\right.$ pyrenyl) [7], and phosphine oxides, $\mathrm{OP}\left(\mathrm{C}_{6} \mathrm{H}_{5}\right)_{2}$ $\left(\mathrm{C}_{10} \mathrm{H}_{7}\right),\left(\mathrm{C}_{10} \mathrm{H}_{7}=\right.$ naphthyl), 1, OP $\left(\mathrm{C}_{6} \mathrm{H}_{5}\right)_{2}\left(\mathrm{C}_{14} \mathrm{H}_{9}\right)$, $\left(\mathrm{C}_{14} \mathrm{H}_{9}=\right.$ phenanthrenyl $), 2, \mathrm{OP}\left(\mathrm{C}_{6} \mathrm{H}_{5}\right)_{2}\left(\mathrm{C}_{14} \mathrm{H}_{9}\right),\left(\mathrm{C}_{14} \mathrm{H}_{9}\right.$ $=$ anthracenyl $), 3$, and $\mathrm{OP}\left(\mathrm{C}_{6} \mathrm{H}_{5}\right)_{2}\left(\mathrm{C}_{16} \mathrm{H}_{9}\right),\left(\mathrm{C}_{16} \mathrm{H}_{9}=\right.$ pyrenyl), $\mathbf{4}$ were synthesized according to literature procedures [8].

\section{$2.2 \mathrm{UO}_{2}\left(\mathrm{NO}_{3}\right)_{2}\left[\mathrm{OP}\left(\mathrm{C}_{6} \mathrm{H}_{5}\right)_{2}\left(\mathrm{C}_{10} \mathrm{H}_{7}\right)\right]_{2}, 5$}

In a $20 \mathrm{~mL}$ scintillation vial, $\mathrm{UO}_{2}\left(\mathrm{NO}_{3}\right)_{2}\left(\mathrm{H}_{2} \mathrm{O}\right)_{6}(100 \mathrm{mg}$, $0.199 \mathrm{mmol})$ was suspended in $10 \mathrm{~mL}$ of THF. $1(171 \mathrm{mg}$, $0.521 \mathrm{mmol}$ ) was added to the mixture and then stirred for $2 \mathrm{~h}$. The solvent was reduced under vacuum to onefifth of the original volume and the compound was then placed in a freezer at $0{ }^{\circ} \mathrm{C}$ overnight to yield a pale orange solid (245 mg, 90\%). ${ }^{1} \mathrm{H}$ NMR $\left(\mathrm{CD}_{2} \mathrm{Cl}_{2}, 500 \mathrm{MHz}, 21^{\circ} \mathrm{C}\right)$ : $\delta$ 6.9-7.8 (m, 20H), 7.1-8.5 ppm (m, 14H) ppm. ${ }^{13} \mathrm{C}$ NMR $\left(\mathrm{CD}_{2} \mathrm{Cl}_{2}, 125 \mathrm{MHz}, 21^{\circ} \mathrm{C}\right): \delta 124.3$ (naph), 126.5 (naph), 127.2 (Ph), 127.5 (naph), 128.7 (Ph), 128.9 (naph), 129.6 (Ph), 131.0 (naph), 132.0 (naph), 132.7 (naph), 133.3 (naph), 133.5 (Ph), 133.8 (naph), 134.0 (naph) ppm. ${ }^{31} \mathrm{P}$ NMR $\left(\mathrm{CD}_{2} \mathrm{Cl}_{2}\right.$, $\left.101 \mathrm{MHz}, 21^{\circ} \mathrm{C}\right): \delta 52.08 \mathrm{ppm}$. IR $\left(\mathrm{KBr}, \mathrm{cm}^{-1}\right): 1548(\mathrm{~s}$, $\mathrm{N}=\mathrm{O}$ ), 1495 (s, C=C), 1474 (s), 1296 (s, $\mathrm{NO}_{3}$ ), 1124 (s, $\mathrm{P}=\mathrm{O}$ ), 1079 (s, P-O), 1024 (w), 935 (s, U=O), 832 (w), 806 (m), $776(\mathrm{~m},=\mathrm{C}-\mathrm{H}), 753(\mathrm{w}), 727(\mathrm{w}), 558(\mathrm{~m}), 543(\mathrm{~s}), 505(\mathrm{w})$. Anal. Calcd for $\mathrm{C}_{44} \mathrm{H}_{34} \mathrm{~N}_{2} \mathrm{O}_{10} \mathrm{P}_{2} \mathrm{U}$ : C, $50.30 \%$; $\mathrm{H}, 3.25 \%$; N, $2.67 \%$. Found: C, $50.18 \%$; H, 3.52\%; N, $2.65 \%$.

\section{$2.3 \mathrm{UO}_{2}\left(\mathrm{NO}_{3}\right)_{2}\left[\mathrm{OP}\left(\mathrm{C}_{6} \mathrm{H}_{5}\right)_{2}\left(\mathrm{C}_{14} \mathrm{H}_{9}\right)\right]_{2}, 6$}

In a $20 \mathrm{~mL}$ scintillation vial, $\mathrm{UO}_{2}\left(\mathrm{NO}_{3}\right)_{2}\left(\mathrm{H}_{2} \mathrm{O}\right)_{6}(100 \mathrm{mg}$, $0.199 \mathrm{mmol}$ ) was suspended in $10 \mathrm{~mL}$ of THF. $2(176 \mathrm{mg}$, $0.465 \mathrm{mmol}$ ) was added to the mixture and then stirred for $2 \mathrm{~h}$. The solvent was reduced in vacuo to one-fifth of the original volume and then placed in a freezer at $0{ }^{\circ} \mathrm{C}$ overnight to yield a pale green-yellow solid (274 $\mathrm{mg}, 99 \%$ ). ${ }^{1} \mathrm{H}$ NMR $\left(\mathrm{CD}_{2} \mathrm{Cl}_{2}, 500 \mathrm{MHz}, 21^{\circ} \mathrm{C}\right): \delta 7.11-7.29(\mathrm{~m}, 4 \mathrm{H}$, $\mathrm{Ph}$ ), 7.43-7.56 (m, 8H, Ph), 7.53-7.68 (m, 8H, Ph), 7.74-7.84 (m, 4H, phenan), 7.81-7.94 (m, 2H, phenan), 8.35-8.41 (m, $4 \mathrm{H}$, phenan), 8.63-8.74 (m, 4H, phenan), 8.76-8.81 (m, $4 \mathrm{H}$, phenan) ppm. ${ }^{13} \mathrm{C}$ NMR $\left(\mathrm{CD}_{2} \mathrm{Cl}_{2}, 125 \mathrm{MHz}, 21{ }^{\circ} \mathrm{C}\right): \delta$ 123.0 (phenan), 123.53 (phenan), 127.4 (Ph), 127.5 (phenan), $128.1(\mathrm{Ph}), 129.0$ (phenan), 129.1 (phenan), 129.6 (phenan), $130.1(\mathrm{Ph}), 130.2$ (phenan), 130.3 (phenan), 131.2 (phenan), 131.4 (phenan), 132.3 (phenan), 132.4 (Ph), 132.8 (phenan), 133.7 (phenan), 137.1 (phenan) ppm. ${ }^{31} \mathrm{P}$ NMR $\left(\mathrm{CD}_{2} \mathrm{Cl}_{2}\right.$, $\left.101 \mathrm{MHz}, 21^{\circ} \mathrm{C}\right): \delta 49.13 \mathrm{ppm}$. IR $\left(\mathrm{KBr}, \mathrm{cm}^{-1}\right): 3061(\mathrm{~m})$, $2974(\mathrm{~m}), 2869$ (m), $1612(\mathrm{w}), 1588$ (m), 1521 (s, N=O), 1438 (s, C=C),1384 (m), 1285 (s, NO ${ }_{3}$ ), 1197 (w), 1134 (s, $\mathrm{P}=\mathrm{O}$ ), 1089 (s, P-O), 1035 (m), 998 (w), 963 (m), 930 (s, $\mathrm{U}=\mathrm{O}), 904(\mathrm{w}), 859(\mathrm{w}), 811(\mathrm{w}), 748(\mathrm{~s},=\mathrm{C}-\mathrm{H}), 721(\mathrm{~s})$, $696(\mathrm{~s}), 610(\mathrm{~m}), 572(\mathrm{~s}), 531(\mathrm{~s}), 517(\mathrm{~m})$. Anal. Calcd for $\mathrm{C}_{52} \mathrm{H}_{38} \mathrm{~N}_{2} \mathrm{O}_{10} \mathrm{P}_{2} \mathrm{U}$ : C, $54.27 \%$; H, 3.33\%; N, 2.43\%. Found: C, 53.18\%; H, 3.67\%; N, 2.40\%.

\section{$2.4 \mathrm{UO}_{2}\left(\mathrm{NO}_{3}\right)_{2}\left[\mathrm{OP}\left(\mathrm{C}_{6} \mathrm{H}_{5}\right)_{2}\left(\mathrm{C}_{14} \mathrm{H}_{9}\right)\right]_{2}, 7$}

In a $20 \mathrm{~mL}$ scintillation vial, $\mathrm{UO}_{2}\left(\mathrm{NO}_{3}\right)_{2}\left(\mathrm{H}_{2} \mathrm{O}\right)_{6}(100 \mathrm{mg}$, $0.199 \mathrm{mmol}$ ) was suspended in $10 \mathrm{~mL}$ of THF. $3(171 \mathrm{mg}$, $0.452 \mathrm{mmol}$ ) was added to the mixture and then stirred for $2 \mathrm{~h}$. The solvent was reduced in vacuo to one-fifth of the original volume and the complex was placed in a freezer at $0{ }^{\circ} \mathrm{C}$ overnight to yield a pale yellow solid (262 mg, 96\%). ${ }^{1} \mathrm{H}$ NMR $\left(\mathrm{CD}_{2} \mathrm{Cl}_{2}, 500 \mathrm{MHz}, 21^{\circ} \mathrm{C}\right): \delta$ $6.99\left(\mathrm{~d}, 8 \mathrm{H}, \mathrm{Ph},{ }^{1} J_{\mathrm{H}-\mathrm{H}}=7 \mathrm{~Hz}\right), 7.14 \mathrm{ppm}\left(\mathrm{t}, 4 \mathrm{H}, \mathrm{Ph},{ }^{1} J_{\mathrm{H}-\mathrm{H}}\right.$ $=7 \mathrm{~Hz}), 7.4-7.6 \mathrm{ppm}(\mathrm{m}, 8 \mathrm{H}$, anth), 7.82-7.90 ppm (m, $8 \mathrm{H}, \mathrm{Ph}), 8.0-8.2(\mathrm{~m}, 8 \mathrm{H}$, anth) 8.47 (s, 2H, anth) ppm. ${ }^{13} \mathrm{C}$ NMR $\left(\mathrm{CD}_{2} \mathrm{Cl}_{2}, 125 \mathrm{MHz}, 21^{\circ} \mathrm{C}\right): \delta 125.4(\mathrm{Ph}), 126.8$ (anth), 129.2 (Ph), 129.7 (anth), 131.7 (anth), 131.8 (Ph), 132.0 (anth), 134.5 (anth), 135.0 (Ph), 135.5 (anth), 135.9 (anth), 136.7 (anth) ppm. ${ }^{31} \mathrm{P}$ NMR $\left(\mathrm{CD}_{2} \mathrm{Cl}_{2}, 101 \mathrm{MHz}, 21^{\circ} \mathrm{C}\right)$ : $\delta 48.19$ ppm. IR (KBr, cm ${ }^{-1}$ ): $3064(\mathrm{w}), 1619(\mathrm{w}), 1517$ (s, $\mathrm{N}=\mathrm{O}$ ), 1438 (s, C=C), 1384 (w), $1284\left(\mathrm{~s}, \mathrm{NO}_{3}\right.$ ), 1125 (s, $\mathrm{P}=\mathrm{O}), 1083$ (s, P-O), 1034 (w), 935 (s, U=O), 844 (w), 824 (w), $756(\mathrm{w}), 737(\mathrm{~m},=\mathrm{C}-\mathrm{H}), 697(\mathrm{~m}), 563(\mathrm{w}), 530(\mathrm{~m})$. Anal. Calcd for $\mathrm{C}_{52} \mathrm{H}_{38} \mathrm{~N}_{2} \mathrm{O}_{10} \mathrm{P}_{2} \mathrm{U}$ : C, $54.27 \%$; $\mathrm{H}, 3.33 \%$; N, $2.43 \%$. Found: C, $53.46 \%$; H, 3.28\%; N, $2.38 \%$. 


\section{$2.5 \mathrm{UO}_{2}\left(\mathrm{NO}_{3}\right)_{2}\left[\mathrm{OP}\left(\mathrm{C}_{6} \mathrm{H}_{5}\right)_{2}\left(\mathrm{C}_{16} \mathrm{H}_{9}\right)\right]_{2}, 8$}

In a $20 \mathrm{~mL}$ scintillation vial, $\mathrm{UO}_{2}\left(\mathrm{NO}_{3}\right)_{2}\left(\mathrm{H}_{2} \mathrm{O}\right)_{6}(100 \mathrm{mg}$, $0.199 \mathrm{mmol}$ ) was suspended in $10 \mathrm{~mL}$ of THF. $4(176 \mathrm{mg}$, $0.438 \mathrm{mmol}$ ) was added to the mixture and then stirred for $2 \mathrm{~h}$. The solvent was reduced in vacuo to one-fifth of the original volume and the complex placed in a freezer at $0{ }^{\circ} \mathrm{C}$ overnight to yield a pale green-yellow solid (274 mg, 99\%). ${ }^{1} \mathrm{H}$ NMR $\left(\mathrm{CD}_{2} \mathrm{Cl}_{2}, 500 \mathrm{MHz}, 21^{\circ} \mathrm{C}\right): \delta 8.92(\mathrm{~d}, 4 \mathrm{H}$, py, $\left.{ }^{1} J_{\mathrm{H}-\mathrm{H}}=9.5 \mathrm{~Hz}\right), 8.25(\mathrm{~m}, 8 \mathrm{H}), 8.08(\mathrm{~m}, 8 \mathrm{H}), 7.79-7.46$ (m, 18H) ppm. ${ }^{13} \mathrm{C}$ NMR $\left(\mathrm{CD}_{2} \mathrm{Cl}_{2}, 125 \mathrm{MHz}, 2{ }^{\circ} \mathrm{C}\right): \delta 123.7$ (py), 125.0 (py), $125.2(\mathrm{Ph}), 125.7$ (py), $126.2(\mathrm{Ph}), 126.4$ (py), 126.5 (py), 126.6 (py), 127.2 (py), 128.7 (Ph), 129.9 (py), 130.4 (py), 130.7 (Ph), 131.3 (py), 132.0 (py), 132.1 (py), 132.2 (py), 133.0 (py), 133.8 (py), 134.3 (py) ppm. ${ }^{31} \mathrm{P}$ NMR $\left(\mathrm{CD}_{2} \mathrm{Cl}_{2}\right.$, $\left.101 \mathrm{MHz}, 21^{\circ} \mathrm{C}\right): \delta 51.21 \mathrm{ppm}$. IR $\left(\mathrm{KBr}, \mathrm{cm}^{-1}\right): 3049(\mathrm{w})$, 2963 (w), 2852 (w), 1626 (w), 1591 (w), 1519 (s, N=O sym str.), 1437 (m), 1384 (s), 1280 (s, asym. str. $\left.\mathrm{NO}_{3}\right) 1208$ (w), 1138 (s, P=O str.), 1097 (s, P-O), 1029 (m), 999 (w), 971 (w), 933 (s, U=O), 928 (m), $856(\mathrm{~m}), 824(\mathrm{w}), 753(\mathrm{w}), 726$ $(\mathrm{w}), 692(\mathrm{~m}), 551(\mathrm{~m}), 528(\mathrm{~m}), 504(\mathrm{w})$. Anal. Calcd for $\mathrm{C}_{52} \mathrm{H}_{38} \mathrm{~N}_{2} \mathrm{O}_{10} \mathrm{P}_{2} \mathrm{U}$ : C, 54.27\%; H, 3.33\%; N, 2.43\%. Found: C, $53.18 \%$; H, 3.67\%; N, $2.40 \%$.

\subsection{Th $\left(\mathrm{NO}_{3}\right)_{4}\left[\mathrm{OP}\left(\mathrm{C}_{6} \mathrm{H}_{5}\right)_{2}\left(\mathrm{C}_{14} \mathrm{H}_{9}\right)\right]_{3}, 9$}

In a $20 \mathrm{~mL}$ scintillation vial, $\mathrm{Th}\left(\mathrm{NO}_{3}\right)_{4}\left(\mathrm{H}_{2} \mathrm{O}\right)_{4}(100 \mathrm{mg}$, $0.181 \mathrm{mmol}$ ) was suspended in $10 \mathrm{~mL}$ of THF. $2(301 \mathrm{mg}$, $0.795 \mathrm{mmol}$ ) was added to the stirring solution and overnight turned a deep red color. The solvent was removed in vacuo to one-fifth of the original volume, and the complex was placed in the freezer at $0{ }^{\circ} \mathrm{C}$ to yield a light yellow powder and polycrystalline beads. The beads were recrystallized out of a concentrated solution of benzene to produce yellow crystalline product of $9(150 \mathrm{mg}, 50 \%$ yield). ${ }^{1} \mathrm{H}$ NMR $\left(\mathrm{CD}_{2} \mathrm{Cl}_{2}, 300 \mathrm{MHz}, 21^{\circ} \mathrm{C}\right): \delta 8.84(\mathrm{~d}$, $\left.6 \mathrm{H},{ }^{1} \mathrm{~J}_{\mathrm{H}-\mathrm{H}}=8 \mathrm{~Hz}\right) .8 .32(\mathrm{bs}, 3 \mathrm{H}),, 7.99-7.89(\mathrm{~m}, 7 \mathrm{H}), 7.85-$ $7.73(\mathrm{~m}, 20 \mathrm{H}), 7.62-7.45(\mathrm{~m}, 12 \mathrm{H})$, 7.41-7.24 (m, 9H) ppm. ${ }^{13} \mathrm{C}$ NMR $\left(\mathrm{CD}_{2} \mathrm{Cl}_{2}, 75 \mathrm{MHz}, 21^{\circ} \mathrm{C}\right): \delta 123.8$ (phenan), 124.3 (Ph), 126.3 (phenan), 128.3 (phenan), $128.5(\mathrm{Ph}), 129.1$ (phenan), 129.2 (phenan), $130.0(\mathrm{Ph}), 130.2$ (phenan), 130.5 (phenan), 131.1 (phenan), 131.5 (phenan), 131.8 (phenan), 133.4 (phenan), 133.6 (phenan), 134.3 (phenan), $139.0(\mathrm{Ph})$, 140.0 (phenan) ppm. ${ }^{31} \mathrm{P}$ NMR $\left(\mathrm{CD}_{2} \mathrm{Cl}_{2}, 101 \mathrm{MHz}, 21{ }^{\circ} \mathrm{C}\right)$ : $\delta 44.9$ ppm. IR (KBr, cm ${ }^{-1}$ ): 3057(w), 1506 (s, N=O), 1438 (s, O-N str.), 1384 (s, P-C), 1299 (s, asym. str. $\mathrm{NO}_{3}$ ), 1127 (s, P=O str.), 1082 (s, P-O str.), 1028(m), 961(w), 810(w), 748(w), 724(s), 693(m), 620(m), 572(m), 533(s, ThO), 499(m). Anal. Calcd for $\mathrm{C}_{52} \mathrm{H}_{38} \mathrm{~N}_{2} \mathrm{O}_{10} \mathrm{P}_{2} \mathrm{U}$ : C, $58.00 \%$;
H, 3.56\%; N, 3.47\%. Found: C, $57.31 \%$; H, 3.80\%; N, $3.55 \%$.

\subsection{Crystallographic data collection and structure determination}

The selected single crystal was mounted on nylon cryoloop using viscous hydrocarbon oil. X-ray data collection was performed at 173(2) or 100(2) K. The X-ray data were collected on a Bruker CCD diffractometer with monochromated Mo $K_{\alpha}$ radiation $(\lambda=0.71073 \AA)$. The data collection and processing utilized the Bruker Apex2 suite of programs [9]. The structures were solved using direct methods and refined by full-matrix least-squares methods on $F^{2}$ using Bruker SHELEX-97 program [10]. All non-hydrogen atoms were refined with anisotropic displacement parameters. All hydrogen atoms were added on idealized positions and not allowed to vary. Thermal ellipsoid plots were prepared by using X-seed [11] with $50 \%$ of probability displacements for non-hydrogen atoms. Crystal data and detail for data collection for complexes 5-9 are provided in Table 1, and significant bond distances and angles are gathered in Tables 4 and 5.

\section{Results and discussion}

\subsection{Synthesis and spectroscopy}

The phosphine oxide ligands, $\mathbf{1 - 4}$, were prepared as previously reported [8]. Reaction of two equivalents of the phosphine oxide ligands with $\mathrm{UO}_{2}\left(\mathrm{NO}_{3}\right)_{2}\left(\mathrm{H}_{2} \mathrm{O}\right)_{6}$ in THF yielded new products as discerned by ${ }^{31} \mathrm{P}$ NMR spectroscopy, Table 2. The phenanthrenyl-substituted phosphine oxide ligand, $\mathrm{OPPh}_{2}\left(\mathrm{C}_{14} \mathrm{H}_{9}\right)$, 2, also coordinates to the thorium metal center when reacted with $\mathrm{Th}\left(\mathrm{NO}_{3}\right)_{4}\left(\mathrm{H}_{2} \mathrm{O}\right)_{4}$, Table 2 . The ligand, 2 , was chosen due to its propensity to form isolable products which can be readily characterized by X-ray diffraction analysis. The uranyl complexes were found to be soluble in THF and $\mathrm{CH}_{2} \mathrm{Cl}_{2}$, but only sparingly soluble in arene solvents, while 9 shows more solubility in toluene. The ${ }^{1} \mathrm{H},{ }^{13} \mathrm{C}$, and ${ }^{31} \mathrm{P}$ NMR spectra for each uranyl complex showed only one set of aryl and phosphorus resonances, indicating a symmetric coordination environment. Coordination of the phosphine oxide to uranyl leads to a downfield shift in the ${ }^{31} \mathrm{P}$ NMR spectrum. This can be attributed to less electron density on the phosphorus atom due to the actinide metal center siphoning electron density from the oxide. There does not seem to be a trend with respect to 
Table 1: X-ray crystallography parameters for complexes 5-9.

\begin{tabular}{|c|c|c|c|c|c|}
\hline & 5 & 6 & 7 & 8 & 9 \\
\hline CCDC Deposit Number & 1005324 & 1005321 & 1005323 & 1005325 & 1005322 \\
\hline Empirical Formula & $\mathrm{C}_{44} \mathrm{H}_{34} \mathrm{~N}_{2} \mathrm{O}_{10} \mathrm{P}_{2} \mathrm{U}$ & $\mathrm{C}_{52} \mathrm{H}_{38} \mathrm{~N}_{2} \mathrm{O}_{10} \mathrm{P}_{2} \mathrm{U}$ & $\mathrm{C}_{52} \mathrm{H}_{38} \mathrm{~N}_{2} \mathrm{O}_{10} \mathrm{P}_{2} \mathrm{U}$ & $\mathrm{C}_{56} \mathrm{H}_{38} \mathrm{~N}_{2} \mathrm{O}_{10} \mathrm{P}_{2} \mathrm{U}$ & $\mathrm{C}_{99} \mathrm{H}_{78} \mathrm{~N}_{4} \mathrm{O}_{15} \mathrm{P}_{3} \mathrm{Th}_{1}$ \\
\hline Formula weight (g/mol) & 1050.70 & 1150.80 & 1150.80 & 1202.87 & 1888.6 \\
\hline Crystal Habit, color & Needle, Colorless & Prism, Colorless & Block, Colorless & Prism, Colorless & Prism, Colorless \\
\hline Temperature (K) & $100(2)$ & $173(2)$ & $173(2)$ & $173(2)$ & $100(2)$ \\
\hline Space group & $P-1$ & $P-1$ & $P 2_{1} / c$ & $P-1$ & $P-1$ \\
\hline Crystal system & Triclinic $P$ & Triclinic $P$ & Monoclinic $P$ & Triclinic $P$ & Triclinic $P$ \\
\hline Volume $\left(\AA^{3}\right)$ & $2023.31(6)$ & $1635.5(3)$ & $2288.57(4)$ & $1307.35(3)$ & $4207.65(5)$ \\
\hline$a(\AA)$ & $9.4887(15)$ & $9.0855(10)$ & $14.383(8)$ & $9.014(2)$ & $12.7596(9)$ \\
\hline$b(\AA)$ & $10.8116(17)$ & $9.7152(10)$ & $9.735(5)$ & $12.511(3)$ & $14.0268(10)$ \\
\hline$c(\AA)$ & $20.710(3)$ & $16.3826(18)$ & $17.526(9)$ & $13.168(3)$ & $25.5719(19)$ \\
\hline$\alpha\left(^{\circ}\right)$ & $102.658(3)$ & $73.856(1)$ & 90.00 & $109.143(3)$ & $89.984(1)$ \\
\hline$\beta\left(^{\circ}\right)$ & $91.102(3)$ & $82.960(1)$ & $111.156(6)$ & $105.180(3)$ & $84.026(10)$ \\
\hline$\gamma\left({ }^{\circ}\right)$ & $101.955(3)$ & $80.505(1)$ & 90.00 & $98.700(3)$ & $67.700(1)$ \\
\hline$Z$ & 2 & 1 & 2 & 1 & 2 \\
\hline Calculated density $\left(\mathrm{Mg} / \mathrm{m}^{3}\right)$ & 1.725 & 1.575 & 1.670 & 1.614 & 1.491 \\
\hline Absorption coefficient $\left(\mathrm{mm}^{-1}\right)$ & 4.153 & 3.10 & 3.68 & 3.23 & 1.90 \\
\hline \multirow[t]{2}{*}{ Final $\mathrm{R}$ indices $[I>2 \sigma(I)]$} & $\mathrm{R} 1=0.0305$ & $\mathrm{R} 1=0.020$ & $\mathrm{R} 1=0.030$ & $\mathrm{R} 1=0.033$ & $\mathrm{R} 1=0.030$ \\
\hline & $w R 2=0.0619$ & $w R 2=0.052$ & $w R 2=0.067$ & $w R 2=0.066$ & $w R 2=0.066$ \\
\hline
\end{tabular}

Table 2: ${ }^{31}$ P NMR chemical shifts for complexes 1-9.

\begin{tabular}{lr}
\hline Compound & $\begin{array}{r}{ }^{31} \mathbf{P} \text { NMR Chemical } \\
\text { Shift (ppm) }\end{array}$ \\
\hline $\mathbf{1}$ & 31.5 \\
$\mathbf{2}$ & 31.8 \\
$\mathbf{3}$ & 34.6 \\
$\mathbf{4}$ & 32.0 \\
$\mathbf{5}$ & 52.1 \\
$\mathbf{6}$ & 48.2 \\
$\mathbf{7}$ & 49.1 \\
$\mathbf{8}$ & 51.2 \\
$\mathbf{9}$ & 44.9 \\
\hline
\end{tabular}

${ }^{31} \mathrm{P}$ NMR chemical shift $v s$. ligand electron withdrawing strength. The ${ }^{31} \mathrm{P}$ NMR spectrum of 9 showed a broad resonance at $44.9 \mathrm{ppm}$, which is unusual for a diamagnetic species. This was attributed to fluxional behavior of the phosphine oxide ligand in solution with two or three ligands coordinated to thorium.

In accordance with the ${ }^{31} \mathrm{P}$ NMR chemical shifts indicative of less electron density on the phosphorus atoms and weakening of the $\mathrm{P}-\mathrm{O}$ bond, the infrared spectra of uranyl complexes, 5-8, have a corresponding red shift of the $\mathrm{P}-\mathrm{O}$ stretching frequency, Table 3. For example, in free $\mathrm{OPPh}_{2}\left(\mathrm{C}_{16} \mathrm{H}_{9}\right)$, 4, a stretch at $1171 \mathrm{~cm}^{-1}$ is observed and is located at $1138 \mathrm{~cm}^{-1}$ in $\mathrm{UO}_{2}\left(\mathrm{NO}_{3}\right)_{2}\left[\mathrm{OPPh}_{2}\left(\mathrm{C}_{16} \mathrm{H}_{9}\right)\right]_{2}, \mathbf{8}$.
Table 3: Infrared stretching frequencies $\left(\mathrm{cm}^{-1}\right)$ of phosphine oxide ligands, 1-4, uranyl, 5-8, and thorium complex, 9.

\begin{tabular}{lrrrrrrrrr}
\hline $\begin{array}{l}\text { Bond stretching } \\
\text { frequency }\left(\mathrm{cm}^{-1}\right)\end{array}$ & $\mathbf{1}$ & $\mathbf{2}$ & $\mathbf{3}$ & $\mathbf{4}$ & $\mathbf{5}$ & $\mathbf{6}$ & $\mathbf{7}$ & $\mathbf{8}$ & $\mathbf{9}$ \\
\hline $\begin{array}{l}v(\mathrm{U}=\mathrm{O})_{\text {asym }} \\
v(\mathrm{P}=\mathrm{O})\end{array}$ & - & - & - & - & 935 & 935 & 930 & 930 & - \\
\hline
\end{tabular}

\subsection{X-ray crystallography analysis}

Single crystal X-ray diffraction analysis of complexes 5-9 was performed to examine their structural features. The structure of 5, Figure 1, exhibits a seven-coordinate complex with $C_{1}$ symmetry, with one of the nitrate ligands coordinating $\kappa^{1}-(0)$ instead of $\kappa^{2}-(0,0)$. The uncoordinated oxygen atom (09) on the nitrate has a hydrogen bond, 2.378 $\AA$, with the closest hydrogen on an adjacent naphthyl ring (H39), Figure $1 \mathrm{~A}$. Due to the $\kappa^{1}-(\mathrm{O})$ bonding of the nitrate ligand, there is a contraction of that $\mathrm{U}-\mathrm{O}$ bond from 2.4813(3) to 2.3720(3) A. The remaining uncoordinated oxygen (O10) also hydrogen bonds with a hydrogen atom (H8) on the adjacent naphthyl ring at $2.671 \AA$, Figure $1 \mathrm{~A}$. However, this effect is only observed in the solid state as the ${ }^{1} \mathrm{H}$ NMR spectrum of 5 indicates that the complex is symmetric.

Complexes 6-8 are all eight-coordinate $\mathrm{UO}_{2}\left(\mathrm{NO}_{3}\right)_{2}\left(\mathrm{OPPh}_{2} \mathrm{Ar}\right)_{2}$ complexes. The U-O (phosphine oxide) bond lengths of 2.3627(16), 2.370(3), and 
Table 4: Structural parameters for complexes 5-8.

\begin{tabular}{lrrrrr}
\hline $\begin{array}{l}\text { Bond distance }(\AA) / \\
\text { angle }\left({ }^{\circ}\right)\end{array}$ & 5 & 6 & 7 & $\mathbf{8}$ \\
\hline $\mathrm{U} 1-\mathrm{O}$ (oxo) & $1.767(2)$ & $1.7661(17)$ & $1.757(3)$ & $1.765(3)$ \\
$\mathrm{U} 1-\mathrm{O}$ (nitrate) & $2.373(2)$ & $2.5179(18)$ & $2.527(3)$ & $2.520(3)$ \\
$\mathrm{U} 1-\mathrm{O}$ (nitrate) & $2.482(2)$ & $2.5406(18)$ & $2.546(3)$ & $2.532(2)$ \\
$\mathrm{U} 1-\mathrm{O}\left(\mathrm{OPPh}_{2}\right.$ Ar) & $2.313(2)$ & $2.3627(16)$ & $2.370(3)$ & $2.343(2)$ \\
$\mathrm{P} 1-\mathrm{O} 4$ & $1.511(2)$ & $1.5066(17)$ & $1.511(3)$ & $1.502(2)$ \\
$\mathrm{O}-\mathrm{U} 1-\mathrm{O}$ (uranyl) & $175.11(3)$ & $180.00(4)$ & 180.0 & 180.0 \\
\hline
\end{tabular}
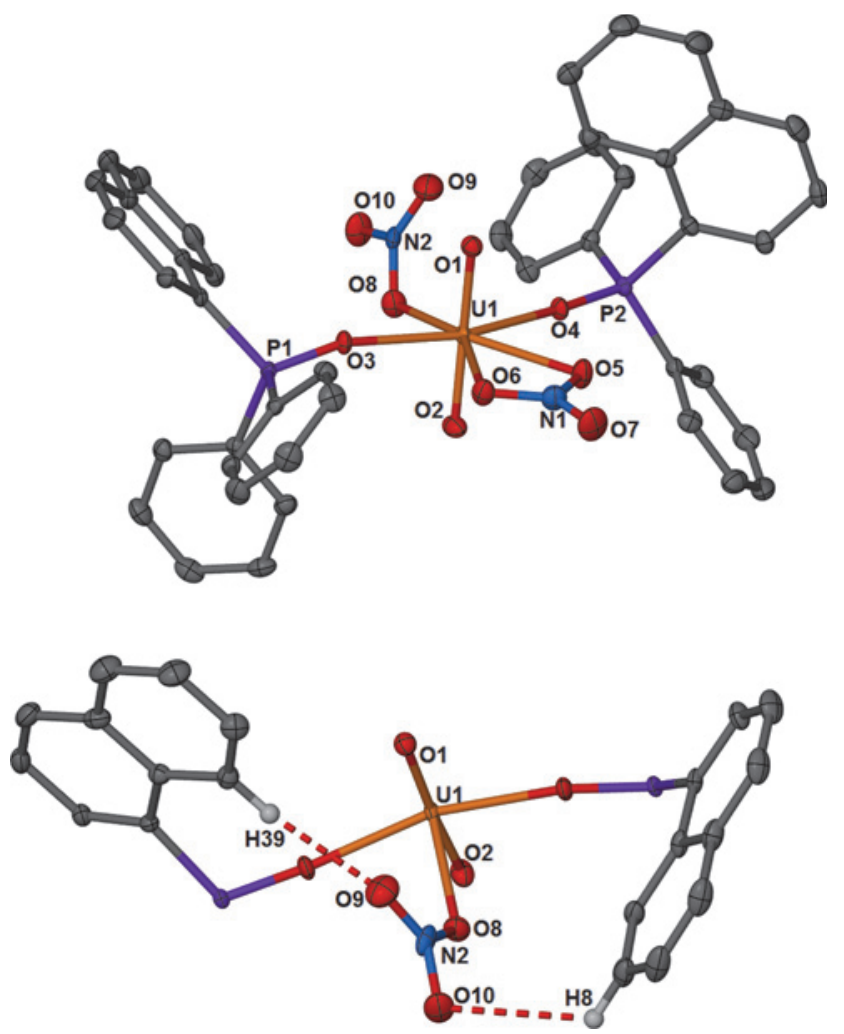

Fig. 1: (Top) Thermal ellipsoid plot of 5 shown at the $50 \%$ probability level. Hydrogen atoms and solvent molecules have been removed for clarity. (Bottom) Thermal ellipsoid plot of 5 with phenyl rings and $\kappa^{2}(0,0)$ nitrate removed. Dotted lines between $\mathrm{H} 39$ and $09(2.378 \AA)$ as well as $\mathrm{H} 8$ and $\mathrm{O} 10$ (2.671 $\AA$ ) have been added to highlight hydrogen bonding.

2.343(2) $\AA$ for 6, Figure 2, 7, Figure 3, and 8, Figure 4, respectively, are nearly identical to $2.35-2.36 \AA$ in $\mathrm{UO}_{2}\left(\mathrm{NO}_{3}\right)_{2}\left(\mathrm{OPPh}_{3}\right)_{2}$. Given that the bond distances and angles compare well to previously reported uranyl complexes of the form $\mathrm{UO}_{2}\left(\mathrm{NO}_{3}\right)_{2}\left(\mathrm{OPR}_{3}\right)_{2}[1,12-25]$, this suggests that PAH- substituted phosphine oxides do not significantly affect sigma donation to the uranium metal center. Another feature in all four complexes is that the PAH is positioned to prevent steric interference, thus even the pyrenyl derivative displays an identical structure

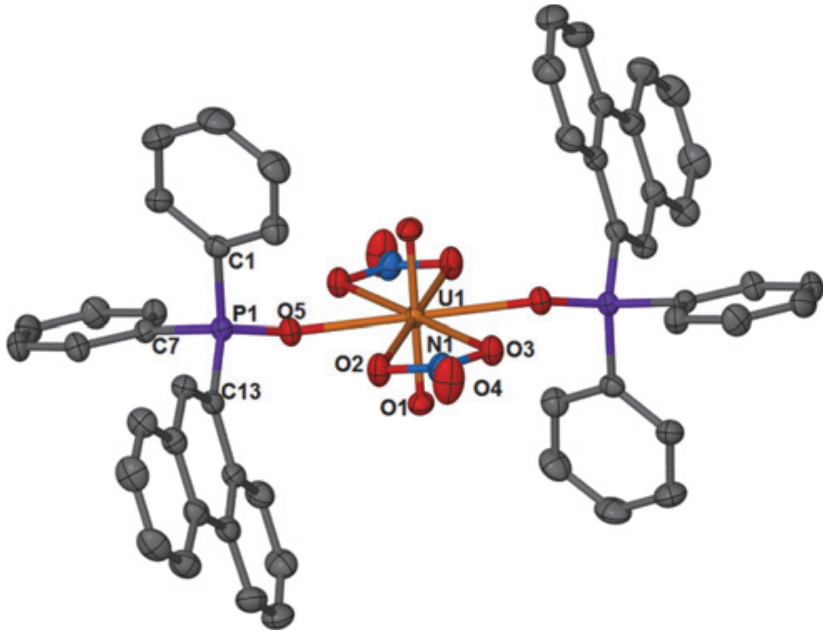

Fig. 2: Thermal ellipsoid plot of 6 shown at the 50\% probability level. Hydrogen atoms and solvent molecules have been removed for clarity.

to the phenanthrenyl and anthracenyl. One feature that warrants mention is a small $\sim 3^{\circ}$ twist from planarity in the anthracenyl ring in 7, Figure 3. The naphthyl, phenanthrenyl, and pyrenyl are all planar and this twist in the anthracenyl ring may have a consequence on the fluorescence spectrum.

Building on the success with uranyl, we also examined the coordination of $\mathbf{2}$ with $\mathrm{Th}\left(\mathrm{NO}_{3}\right)_{4}$. The solidstate structure of 9 revealed an eleven-coordinate complex with $\mathrm{Th}\left(\mathrm{NO}_{3}\right)_{4}$ and three $\mathrm{OPPh}_{2}\left(\mathrm{C}_{14} \mathrm{H}_{9}\right)$ ligands coordinated, Figure 5. While NMR spectroscopy has detected thorium complexes with three coordinated phosphine oxide ligands [26, 27], this appears to be the first isolated structure. As previously mentioned, the ${ }^{31} \mathrm{P}$ NMR spectrum of 9 showed a broad resonance and this is most likely due to the fluxional behavior of one of the phosphine oxide ligands associating and dissociating from the thorium center. The increased coordination number also has the effect of forcing a pair of the nitrates to be nonlinear and angle towards the coordination site of the single phosphine oxide with an N-Th-N angle of $149.40^{\circ}$. However, the thorium-oxygen bond lengths of the nitrate ligands in 9 of 2.39 to $2.41 \AA$ compare well to those of $2.31-2.35 \AA$ in $\mathrm{Th}\left(\mathrm{NO}_{3}\right)_{4}\left(\mathrm{OPMe}_{3}\right)_{2}$ and $2.33-2.35 \AA$ $\mathrm{Th}\left(\mathrm{NO}_{3}\right)_{4}\left(\mathrm{OPPh}_{3}\right)_{2}$.

\subsection{Optical spectroscopy}

The electronic absorbance spectra for the aromatic phosphine oxide ligands 1-4 in THF are provided in Figure 6 and accord well with the absorbance profiles expected for 

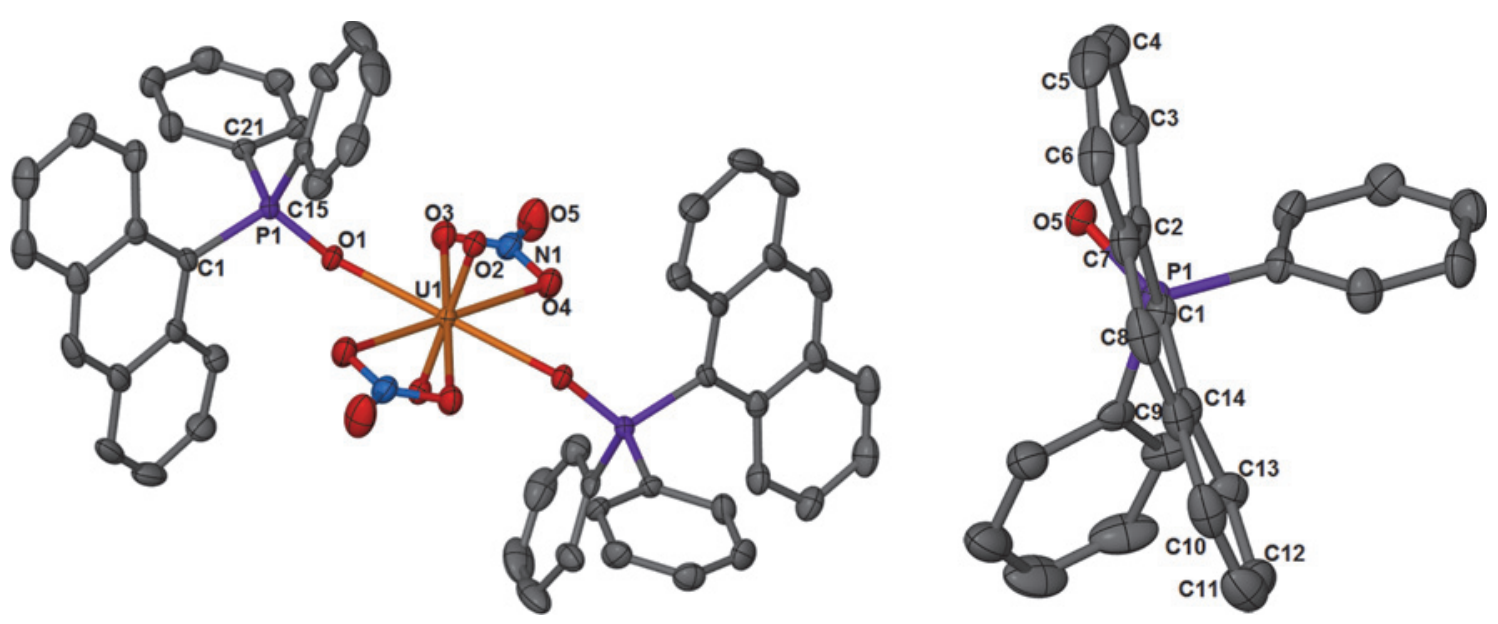

Fig. 3: (Left) Thermal ellipsoid plot of 7 shown at the $50 \%$ probability level. Hydrogen atoms and solvent molecules have been removed for clarity. (Right) Twist in anthracenyl ligand from planarity is shown.

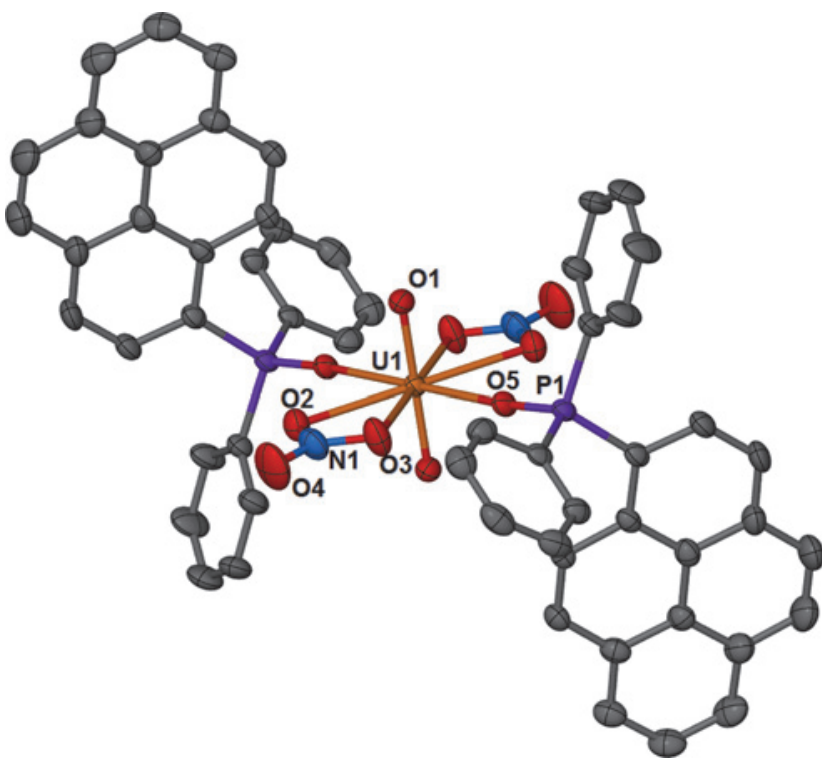

Fig. 4: Thermal ellipsoid plot of 8 shown at the $50 \%$ probability level. Hydrogen atoms and solvent molecules have been removed for clarity.

the parent PAH compounds. The corresponding fluorescence excitation and emission spectra are shown in Figure 7. Consistent with an earlier report, the phosphines were observed to be non-fluorescent [8]. The order of the emission intensities for their oxides, however, is $4>3 \gg$ $\mathbf{2} \gg \mathbf{1}$ with ligands $\mathbf{1}-\mathbf{3}$ showing relative intensities of roughly $2.4 \%, 11 \%$, and $51 \%$, respectively, when compared to the intensity from the 1-pyrenyl ligand 4 . Interestingly, the emission observed from the 9-anthryl phosphine oxide ligand $\mathbf{3}$ is structureless and red-shifted by $c a$. $50 \mathrm{~nm}$ relative to typical anthracene monomer emission, which shows vibronic character. In fact, this was also

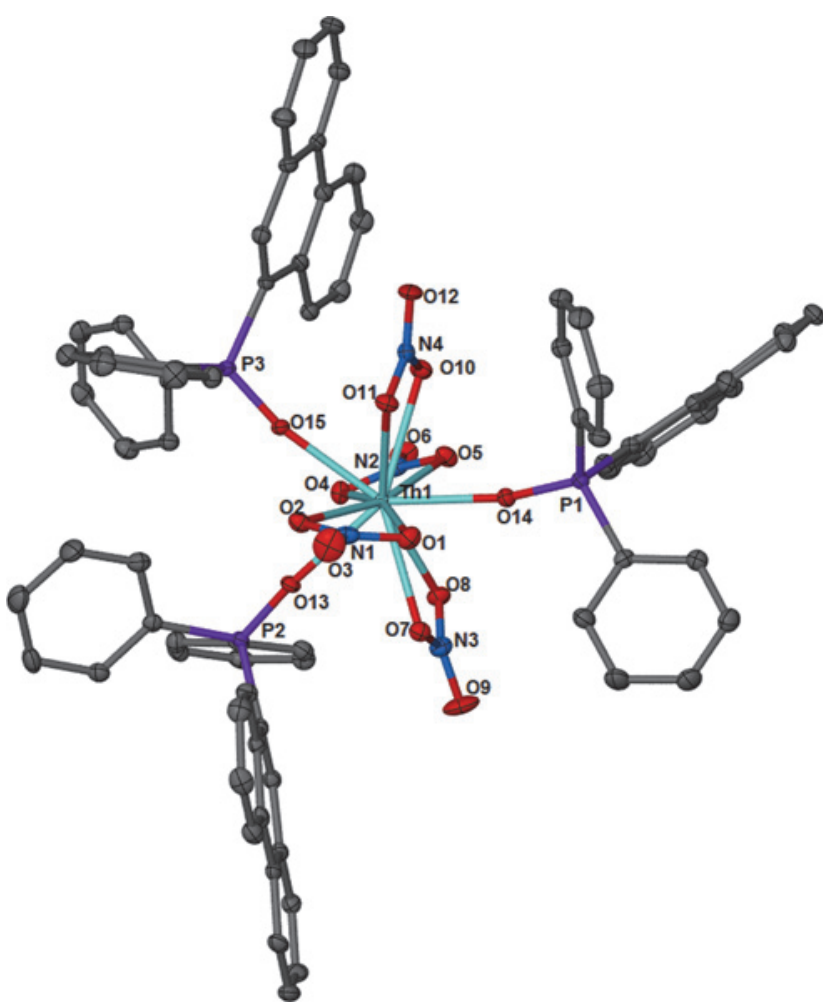

Fig. 5: Thermal ellipsoid plot of 9 shown at the 50\% probability level. Hydrogen atoms and solvent molecules have been removed for clarity.

seen in earlier work from Akasaka et al. [8], but was not specifically mentioned. Broad, red-shifted emission from PAHs is frequently associated with excited-state dimer (excimer) formation; however, this seems an unlikely explanation for the photophysical behavior given the fact that we are operating at highly dilute conditions where intermolecular association during the excited-state lifetime is 
Table 5: Selected bond distances $(\AA \AA)$ and angles $\left({ }^{\circ}\right)$ for 9.

\begin{tabular}{lr}
\hline Bond distance $(\AA)$ /angle $\left(^{\circ}\right)$ & 9 \\
\hline Th-O1 (nitrate) & $2.6293(18)$ \\
Th-O2 (nitrate) & $2.5600(18)$ \\
Th-O4 (nitrate) & $2.6109(18)$ \\
Th-O5 (nitrate) & $2.5973(18)$ \\
Th-O7 (nitrate) & $2.6268(18)$ \\
Th-O8 (nitrate) & $2.5866(19)$ \\
Th-O10 (nitrate) & $2.6098(18)$ \\
Th-O11 (nitrate) & $2.5925(18)$ \\
Th-O13 (OPPh 2 Ar) & $2.4108(17)$ \\
Th-O14 (OPPh 2 Ar) & $2.3914(17)$ \\
Th-O15 (OPPh & Ar) \\
P2-O13 & $2.3954(17)$ \\
P1-O14 & $1.5053(18)$ \\
P3-O15 & $1.5161(18)$ \\
O-Th-O (phosphines) & $1.5116(18)$ \\
& $140.28(6)$ \\
N-Th-N (nonlinear & $142.31(6)$ \\
nitrates) & $77.41(6)$ \\
\end{tabular}

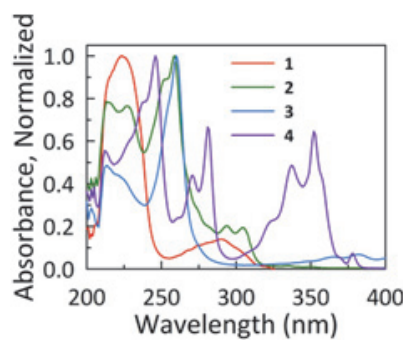

Fig. 6: Normalized UV-vis absorption spectra of phosphine oxide ligands 1-4 in THF.

unlikely. We tentatively attribute this spectral shift to the bending of the anthracene ring witnessed for this ligand in its uranyl complex (vide supra). However, at this point, it is not clear if the same non-planar geometry is assumed for the ring in the free phosphine oxide ligand. This represents a fundamental difference from the results for ligands 1, 2 and $\mathbf{4}$ in which the emission appears typical of the monomer-type emission expected on the basis of the parent PAH.

The fluorescence spectra for the uranyl complexes, 58, were also attempted in THF solution at $\mathrm{mM}$ concentrations, but it was found that the phosphine oxide ligands dissociated at dilute concentration. This was verified by ${ }^{31} \mathrm{P}$ NMR spectroscopy of the $1 \mathrm{mM}$ stock solution which showed the presence of free ligand only. Thus, the fluorescence profile was identical to that of the free ligand and the spectroscopy of the uranyl complexes could not be satisfactorily obtained.

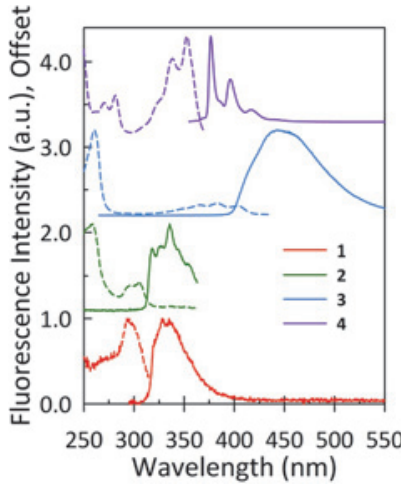

Fig. 7: Normalized excitation (broken profiles) and emission spectra (solid lines) of aromatic phosphine oxide ligands 1-4 in THF at a concentration of $2 \times 10^{-5} \mathrm{M}$. The emission and excitation wavelengths used to record these spectra were $320 / 290,368 / 260$, $440 / 260$, and $377 / 337 \mathrm{~nm}$ for compounds 1, 2, 3, and 4, respectively.

\section{Conclusion}

We have synthesized and characterized through ${ }^{1} \mathrm{H},{ }^{13} \mathrm{C}$, and ${ }^{31} \mathrm{P}$ NMR, as well as IR, UV-Vis, and fluorescence spectroscopy, a series of phosphine oxide ligands bearing a polycyclic aromatic hydrocarbon. Two ligands coordinate to $\mathrm{UO}_{2}\left(\mathrm{NO}_{3}\right)_{2}$ to form eight-coordinate complexes which were also characterized by X-ray crystallography. In addition, for the first time three phosphine oxide ligands were structurally observed to bind to $\mathrm{Th}\left(\mathrm{NO}_{3}\right)_{4}$ to produce an eleven-coordinate species. The fluorescence spectrum of the anthracenyl-substituted phosphine oxide ligand showed no vibronic coupling and was red-shift approximately $50 \mathrm{~nm}$ from free anthracene, providing possible opportunities for use in detection. In the future, we plan to study the stability of these complexes under radiolysis conditions.

Acknowledgement: This material is based upon work supported by the U.S. Department of Homeland Security under Grant Award Number, 2012-DN-130-NF0001-02. The views and conclusions contained in this document are those of the authors and should not be interpreted as necessarily representing the official policies, either expressed or implied, of the U.S. Department of Homeland Security. We also acknowledge the Nuclear Regulatory Commission (NRC) Faculty Development Award for financial support.

\section{References}

1. Alcock NW, Roberts MM, Brown D: Actinide structural studies. Part 1. Crystal and molecular structures of dinitratodioxo- 
bis(triphenylphosphine oxide)neptunium(VI), dinitratodioxobis(triphenylphosphine oxide)uranium(VI), and dichlorodioxo(triphenylphosphine oxide)neptunium(VI). J. Chem. Soc., Dalton Trans. 25-31 (1982).

2. Charushnikova IA, Krot NN, Starikova ZA: Crystal structure of a complex of $\mathrm{Pu}(\mathrm{VI})$ nitrate with triphenylphosphine oxide, $\left[\mathrm{PuO}_{2}\left(\mathrm{NO}_{3}\right)_{2}\left(\mathrm{OP}\left(\mathrm{C}_{6} \mathrm{H}_{5}\right)_{3}\right)_{2}\right]$. Radiochemistry 49 561-4 (2007).

3. Bombieri G, Forsellini E, Day JP, Azeez WI: Crystal and molecular structure of dichlorodioxobis(triphenylphosphine oxide)uranium(VI). J. Chem. Soc., Dalton Trans. 677-680 (1978).

4. Panattoni C, Graziani R, Bandoli G, Zarli B, Bombieri G: Chemistry of the uranyl group. II. Preparation and properties of triphenylphosphine oxide and triphenylarsine oxide complexes of uranyl acetate and the structure of $\left(\mathrm{UO}_{2}\left(\mathrm{CH}_{3} \mathrm{COO}\right)_{2}\left(\mathrm{C}_{6} \mathrm{H}_{5}\right)_{3} \mathrm{PO}\right)_{2}$. Inorg. Chem. 8, 320-325 (1969).

5. Gillens A, Powell B: Rapid quantification of TBP and TBP degradation product ratios by FTIR-ATR. J. Radioanal. Nucl. Chem. 296, 859-868 (2013).

6. Allen DV, Venkataraman D: Copper-Catalyzed Synthesis of Unsymmetrical Triarylphosphines. J. Org. Chem. 68, 45904593 (2003).

7. Arrigo LM, Galenas M, Bassil DB, Tucker SA, Kannan R, Katti KV, et al.: Fluorescent phosphinimine as possible precursor to an anionic and fluorescent sensor for Tc-99. Radiochim. Acta 96, 835-844 (2008).

8. Akasaka K, Suzuki T, Ohrui H, Meguro H: Study on Aromatic Phosphines for Novel Fluorometry of Hydroperoxides (I) Synthesis and Spectral Properties of Diphenyl Aryl Phosphines and Their Oxides. Anal. Lett. 20, 731-745 (1987).

9. Apex II suite Bruke AXS Ltd., 2006, Madison, WS.

10. Sheldrick G: A short history of SHELX. Acta Cryst. A 64, 112-122 (2008).

11. Barbour LJ: X-Seed - A Software Tool for Supramolecular Crystallography. J. Supramol. Chem. 1, 189-191(2001).

12. Matveeva AG, Grigoriev MS, Dvoryanchikova TK, Matveev SV, Safiulina AM, Sinegribova OA, et al.: Complexes of (2-methyl4-oxopent-2-yl)diphenylphosphine oxide with uranyl and neodymium nitrates: synthesis and structures in the solid state and in solution. Russ. Chem. Bull. 61, 399-404 (2012).

13. Agostini G, Giacometti G, Clemente DA, Vicentini M: Crystal and molecular structure of uranyl nitrate trimethylphosphate. Inorg. Chim. Acta 62, 237-240 (1982).

14. Babecki R, Platt AWG, Tebby JC, Fawcett J, Russell DR, Little R: The crystal and molecular structure of $\mathrm{UO}_{2}\left(\mathrm{NO}_{3}\right)_{2}\left[\mathrm{Ph}_{2} \mathrm{P}(\mathrm{O}) \mathrm{CH}_{2} \mathrm{C}(\mathrm{O}) \mathrm{Ph}\right]_{2}$ and its role in the solvent extraction of the uranyl ion. Polyhedron 8, 1357-1360 (1989).

15. Burns JH: Solvent-extraction complexes of the uranyl ion. 1. Crystal and molecular structure of bis(nitrato)bis(tri- $n$ butylphosphine oxide)dioxouranium(VI). Inorg. Chem. 20, 3868-3871 (1981).
16. Burns JH, Brown GM, Ryan RR: Structure of dinitratodioxobis(triisobutyl phosphate)uranium(VI) at $139 \mathrm{~K}$. Acta Cryst. C 41, 1446-1448 (1985).

17. Casellato U, Fregona D, Tamburini S, Vigato PA, Graziani R: Synthesis and characterization of uranyl(VI) and thorium(IV) complexes with phosphine oxides. The crystal structure of $\mathrm{UO}_{2}\left(\mathrm{NO}_{3}\right)_{2}\left(\mathrm{NO}_{2} \mathrm{C}_{6} \mathrm{H}_{4} \mathrm{Ph}_{2} \mathrm{PO}\right)_{2}$. Inorg. Chim. Acta 110, 41-46 (1985).

18. Charpin P, Lance M, Soulie E, Vigner D: Structure du dinitratodioxobis(triamide hexamethylphosphorique)uranium(VI), $\left[\mathrm{UO}_{2}\left(\mathrm{NO}_{3}\right)_{2}\left(\mathrm{C}_{6} \mathrm{H}_{18} \mathrm{~N}_{3} \mathrm{OP}\right)_{2}\right]$. Acta Cryst. C 41, 884-886 (1985).

19. Conary GS, Duesler EN, Paine RT: Coordination chemistry of 2diethylphosphonato-4,6-dipiperidino-1,3,5-triazine with uranyl nitrate. Inorg. Chim. Acta 145, 149-156 (1988).

20. Cromer DT, Ryan RR, Karthikeyan S, Paine RT: Structural studies of uranyl complexes of diphenyl-dimethylaminosulfonylmethyl phosphine oxide and diisopropyl-tolylsulfinylmethyl phosphonate ligands. Inorg. Chim. Acta 172, 165-172 (1990).

21. de Aquino AR, Bombieri G, Isolani PC, Vicentini G, ZukermanSchpector J: Characterization, luminescence and crystal structure of uranyl nitrate complexes with diphenyl-Nethylphosphine amide and tripiperidinephosphine oxide. Inorg. Chim. Acta 306, 101-105 (2000).

22. Henderson W, Leach MT, Nicholson BK, Wilkins AL, Hoye PAT: Uranyl nitrate complexes of camphene-derived organophosphorus ligands, and the X-ray crystal structure of $\left[\mathrm{UO}_{2}\left(\mathrm{NO}_{3}\right)_{2}\left(\mathrm{RPO}_{3} \mathrm{Me}_{2}\right)_{2}\right]$ ( $\mathrm{R}=$ endo-8-camphanyl). Polyhedron 17 3747-52 (1998).

23. Kanellakopulos B, Dernberger E, Maier R, Nuber B, Stammler HG, Ziegler ML: Molekülstruktur und Ladungsverteilung.IV. Elektrisches Dipolmoment von 1:2-Addukten des Uranylnitrats mit Trialkylphosphaten. Die Kristallstruktur von $\mathrm{UO}_{2}(\mathrm{TEP})_{2}\left(\mathrm{NO}_{3}\right)_{2}$ und Bis[( $\mu$-diethylphosphato-O-O')nitrato(triethyl-phosphato)dioxouran(VI)], $\left.\left.\left\{\mathrm{UO}_{2}\right)\left[(\mathrm{EtO})_{2} \mathrm{PO}_{2}\right](\mathrm{EtO})_{3} \mathrm{PO}\right]\left(\mathrm{NO}_{3}\right)\right\}_{2}$. Z. Anorg. Allg. Chem. 619, 593-600 (1993).

24. Karthikeyan S, Ryan RR, Paine RT: Synthesis and coordination properties of (sulfinylmethyl)phosphonates and (sulfonylmethyl)phosphonates. Crys-

tal and molecular structure determinations for $\mathrm{UO}_{2}\left(\mathrm{NO}_{3}\right)_{2}\left[\left(\text { iso }-\mathrm{C}_{3} \mathrm{H}_{7} \mathrm{O}\right)_{2} \mathrm{P}(\mathrm{O}) \mathrm{CH}_{2} \mathrm{~S}(\mathrm{O})_{2} \mathrm{C}_{6} \mathrm{H}_{11}\right]_{2}$ and $\mathrm{Gd}\left(\mathrm{NO}_{3}\right)_{3}\left[\left(\text { iso }-\mathrm{C}_{3} \mathrm{H}_{7} \mathrm{O}\right)_{2} \mathrm{P}(\mathrm{O}) \mathrm{CH}_{2} \mathrm{~S}(\mathrm{O})\left(\mathrm{p}-\mathrm{CH}_{3} \mathrm{C}_{6} \mathrm{H}_{4}\right)\right] \cdot \mathrm{H}_{2} \mathrm{O}$. Inorg. Chem. 28, 2783-2789 (1989).

25. Znovjyak KO, Ovchynnikov VA, Sliva TY, Shishkina SV, Amirkhanov VM: Bis(N-\{bis[methyl(phenyl)amino]phosphoryl\}2,2,2-trichloroacetamide)dinitratodioxidouranium(VI). Acta Cryst. E 66, m306 (2010).

26. du Preez JGH, van Vuuren CPJ: The chemistry of uranium. Part XII. Nitrate complexes of uranium(IV) and thorium(IV). J. Chem. Soc., Dalton Trans. 1548-1552 (1975).

27. Bagnall KW, Wakerley MW: Phosphine oxide complexes of thorium(IV), uranium(IV), neptunium(IV), and dioxouranium(VI) nitrates. J. Chem. Soc., Dalton Trans. 889-895 (1974). 